Heart Attack! 


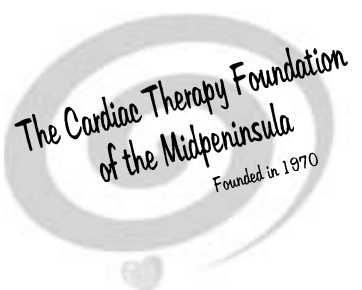

The Cardiac Therapy Foundation of the Midpeninsula, founded in 1970 in Palo Alto, California, is a unique cardiac rehabilitation program, currently owned and operated by the heart attack patients themselves. Its well-qualified staff provides a full range of assistance, including exercise classes, social support, stress reduction groups, nutritional counseling, and health education. The Foundation has helped thousands of heart attack patients to lead healthier, longer, and more vibrant lives. 


\section{HEART ATTACK!}

Advice for Patients by Patients

Kathleen Berra

Gerald W. Friedland

Christopher Gardner

Francis H. Koch

Donna Louie

Nancy Houston Miller

Robin Wedell

with

Barton Thurber

YALE UNIVERSITY PRESS New Haven and London 
The information and suggestions contained in this book are not intended to replace the services of your physician or caregiver. Because each person and each medical situation is unique, you should consult your own physician to get answers to your personal questions, to evaluate any symptoms you may have, or to receive suggestions on appropriate medications.

The authors have attempted to make this book as accurate and up-to-date as possible, but it may nevertheless contain errors, omissions, or material that is out of date at the time you read it. Neither the authors nor the publisher have any legal responsibility or liability for errors, omissions, out-of-date material, or the reader's application of the medical information or advice contained in this book.

Copyright (c) 2002 by the Cardiac Therapy Foundation of the Midpeninsula. All rights reserved.

This book may not be reproduced, in whole or in part, including illustrations, in any form (beyond that copying permitted by Sections 107 and 108 of the U.S. Copyright Law and except by reviewers for the public press), without written permission from the publishers.

Set in the Stone Clan types by Tseng Information, Durham, North Carolina. Printed in the United States of America by Vail-Ballou Press, Binghamton, New York.

\section{Library of Congress Cataloging-in-Publication Data}

Heart attack : advice for patients by patients / Kathleen Berra ... [et al.].

p. $\mathrm{cm}$.

Includes bibliographical references and index.

ISBN 0-300-08980-5 (cloth : alk. paper)-

ISBN 0-300-09190-7 (pbk. : alk. paper)

1. Myocardial infarction-Popular works. I. Berra, Kathy. RC685.I6 H425 2001

616.1'237-dc21 2001033256

A catalogue record for this book is available from the British Library.

$\otimes$ The paper in this book meets the guidelines for permanence and durability of the Committee on Production Guidelines for Book Longevity of the Council on Library Resources. 
In loving memory

of Jerry Fox, a man of ideas 
